\title{
Pensononowoor
}

2021 , vol. $86,19-28$

https://doi.org/10.12657/denbio.086.003

\author{
Andrés González-Melo
}

\section{Radial variations in wood density, and their implications for above-ground biomass estimations, in a tropical high-andean forest}

\author{
Received: 18 March 2021; Accepted: 21 July 2021
}

\begin{abstract}
Wood density (WD) is a central trait to explain tree functioning, and is also an important predictor of tree above-ground biomass (AGB). Therefore, radial trends in WD (i.e., from pith to bark) may have important implications in understanding tree life-history variations, as well as in forest biomass and carbon estimations. The occurrence of these radial trends in WD is thought to vary among forests, particularly with canopy openness and stratification. Yet, most of the studies on this topic in tropical forests have been conducted on lowland closed-canopy forests, while very little is known about the prevalence and magnitude of these trends among trees from open-canopy forests, such as high-mountain forests.

I examined radial gradients in WD and explored their implications for AGB estimations.

Radial wood cores were taken with increment borers from 69 trees belonging to 18 species from a high-Andean forest. Each wood core was cut every 1-cm, and WD was measured for every 1-cm segment. Errors in AGB estimations that resulted from not considering radial trends in WD were estimated for each tree and species.

Eight out of eighteen species had significant radial trends in WD. Among these species, two species showed decreases of WD towards the bark, one species showed increments of WD from pith to bark, and five species showed U-shaped gradients (i.e., high WD near the pith and bark, and relatively low WD at intermediate diameters). The prevalence of U-shaped radial trends in WD may be related to the relatively open and less stratified canopy of the study forest. Not taking into account radial trends in WD led in general to under-estimations of AGB (averaging $-7.66 \%$ when using mean WD, and $-5.56 \%$ for outer WD) in most of the study species, suggesting that tropical high-Andean forests may possibly store more biomass carbon than has been previously estimated.

These findings are important to expand our knowledge on wood allocation patterns during tree ontogeny, and also to improve the accuracy of biomass and carbon estimations in tropical high-Andean forests.
\end{abstract}

Keywords: wood density, above-ground biomass, radial variations, tropical high-Andean trees

Adresses: A.G. Melo, Biology Department, Faculty of Natural Sciences, Universidad del Rosario, Carrera 24 \# 63C-69, Bogotá, Colombia, e-mail: germana.gonzalez@urosario.edu.co;

(D) https://orcid.org/0000-0003-0069-456X 


\section{Introduction}

Wood density (WD, $\mathrm{g} \mathrm{cm}^{-3}$ ) is a commonly measured plant trait (e.g., Chave et al., 2009), and is considered a central trait to understand tree functioning and performance (e.g., Chave et al., 2009; Visser et al., 2016). For instance, WD is generally related to wood hydraulic (Santiago et al., 2004, 2019) or mechanical properties (King et al., 2006); and has been suggested to balance a trade-off between stem construction and maintenance costs, with low-WD species achieving needed stem strength at a lower construction cost (e.g., Anten \& Shieving, 2010), and high-WD species having lower stem maintenance costs (Larjavaara \& Muller-Landau, 2010). Furthermore, WD also plays a key role in forest biomass and carbon estimations, as it is usually the second most important predictor, after stem size, of above-ground biomass (Chave et al., 2014).

It is well established that WD can vary substantially along environmental gradients (Wiemann \& Williamson, 2002; Ter Steege et al., 2006). For example, a number of studies have shown that WD tends to decrease with soil fertility (e.g., Muller-Landau, 2004; Ter Steege et al., 2006; Fortunel et al., 2013) or with mean annual precipitation (e.g., Wiemann \& Williamson, 2002; Chave et al., 2009; Martínez-Cabrera et al., 2009). Moreover, the literature indicates that WD varies considerably across species (e.g., Muller-Landau, 2004, Chave et al., 2009). In particular, WD is related to successional position and then reflects a slow-fast continuum in plant performance, where slow-growing species typically have dense wood (Muller-Landau, 2004; Chave et al., 2009; Plourde et al., 2015).

Wood density can also vary radially within stems (i.e., from pith to bark) during tree ontogeny (e.g., Williamson \& Wiemann, 2010a; Lachenbruch et al., 2011). Yet, in biomass estimation studies, these radial changes in WD have received much less attention in comparison to interspecific or environmental variation of WD. In general, there are three main patterns of radial variations in WD. Positive patterns (i.e., increments of WD towards the bark) that are typical of fast-growing species (Wiemann \& Williamson, 1989; Williamson \& Wiemann, 2010a), negative ones (i.e., decreases of WD) that tend to be common among slow-growing species (Hietz et al., 2013; Plourde et al., 2015), and U-shaped patters in which wood is dense near the pith and bark, but light at intermediate stem diameters (Williamson et al., 2012; Osazuwa-Peters et al., 2014).

Different factors, that are not mutually exclusive, may explain the occurrence of these radial changes in WD. First, the age of the vascular cambium that can influence the size of wood cells (Lachenbruch et al., 2011; Williamson \& Wiemann, 2010a). Second, the deposition of wood extractives, in heartwood or sapwood, that can affect WD via increments in wood mass (Lehnbach et al., 2019). Third, the size of stems because trees can adjust their wood in response to changes in mechanical, storage and hydraulic demands during ontogeny (Nock et al., 2009; Rungwattana \& Hietz, 2017). In addition, a number of studies have suggested that radial trends in WD may reflect, to some extent, the temporal and spatial shifts in light availability that trees experience as they grow (e.g., Woodcock \& Shier, 2002; Williamson \& Wiemann, 2010a; Hietz et al., 2013; Osazuwa et al., 2014). For instance, juveniles of light-demanding species typically produce light wood to favor fast growth in gap openings and later, as adults, they tend to produce denser wood, probably to enable crown expansion and increase mechanical stability (Williamson \& Wiemann, 2010a; Osazuwa et al., 2014). In contrast, shade-tolerant species generally start producing dense wood which may be advantageous to survive in the shaded understory, and when they reach more favorable canopy layers, they produce lighter wood likely to increase their height and diameter growth (Woodcock \& Shier, 2002; Hietz et al., 2013).

If radial shifts in WD are related to both vertical (i.e., from the understory to the canopy) and horizontal (i.e., via gap openings) gradients in light availability (Woodcock \& Shier, 2002), then it is likely that these radial shifts in WD vary among forests that differ in terms of canopy openness and stratification (e.g., Wiemann \& Williamson, 1989). Yet, evidence supporting this idea is limited, particularly for tropical forest trees (Wiemann \& Williamson, 1989), mainly because most studies on this topic in tropical forests have been conducted in lowland and closed-canopy forests (Williamson \& Wiemann, 2010a; Hietz et al., 2013; Plourde et al., 2015; Osazuwa-Peters et al., 2014), while very few have been done in more open-canopy forests such as tropical high-Andean forests (but see Wiemann \& Williamson, 1989). This limits our understanding of ontogenetic shifts in wood allocation patterns and tree functioning among tropical mountain trees.

Beyond its functional significance (e.g., Chave et al., 2009), WD is also a key predictor of above-ground biomass (AGB; Chave et al., 2014). Some studies on AGB estimations, particularly at larger scales, use averaged WD values, at the species, genus or family level (e.g., Zanne et al., 2009); or values from branches or the outer part of the trunk (e.g., Baraloto et al., 2012). However, not taking into account radial trends in WD may lead to biases in AGB estimations (Nock et al., 2009; Schüller et al., 2013; Plourde et al., 2015). For example, the use of WD values from the outer part of the stem may cause over-estimations of AGB in fast-growing species (e.g., Nock et al., 2009), 
as in these species WD is typically higher in outer than in inner wood (e.g., Williamson \& Wiemann, 2010a), while the opposite trend (i.e., under-estimations in AGB) would be expected for slow-growing species (e.g., Schüller et al., 2013).

High-Andean forests of central Colombia are part of the Tropical Andes Biodiversity Hotspot, which is considered a global center of endemism and biodiversity (Myers et al., 2000; Mittermier et al., 2003). These forests also play a central role in the provision of ecosystem services such as carbon storing and water regulation (Armenteras et al., 2003; Torres et al., 2012). However, despite the relevance of these forests, several aspects of their ecology and functioning are still poorly understood. The aim of this study is to increase our understanding of ontogenetic trends in wood and biomass allocations across 18 tree species, with contrasting shade-tolerance, from a tropical high-Andean forest. In particular, I wanted to answer the following questions: (i) How does WD change with stem diameter? and (ii) How do radial changes in WD affect above-ground biomass estimations?

\section{Methods}

\section{Study site}

The study was conducted in a high-Andean forest located in Guasca $\left(04^{\circ} 51^{\prime} \mathrm{N}, 73^{\circ} 41^{\prime} \mathrm{W}\right)$, central Colombia, at $2950 \mathrm{~m}$ of elevation. The rainfall pattern in the region is unimodal with a distinct rainy season peaking in July. Mean annual temperature is $13^{\circ} \mathrm{C}$ and rainfall averages $1714 \mathrm{~mm}$ per year (Cantillo et al., 2004). Floristic composition of canopy trees is similar to other nearby high-Andean forests (Cantillo et al., 2004; Avella et al., 2014), and dominant families in the canopy include Clusiaceae, Cunoniaceae, Chrysobalanaceae and Myrsinaceae (personal observation.). The forest was subjected to selective logging of valuable timber species (i.e., Lauraceae spp.) 40-50 years ago. However, based on forest structure and floristic composition, the forest is considered mature.

\section{Species selection and sampling}

Eighteen of the most abundant tree species in the canopy and subcanopy were randomly selected, and classified as light-demanding, long-lived light-demanding, or shade-tolerants based on their regeneration light requirements (Mahecha et al., 2012). To measure wood density, core samples were taken to the center of the stem and at breast height $(1.3 \mathrm{~m})$, using a $12-\mathrm{mm}$ increment borer (Williamson \& Wiemann, 2010b). One core sample was obtained per individual, in three to five individuals per species, for a total of 69 trees. Whenever possible, trees without visible injuries or leaning stems were sampled, as these factors could affect WD measures. Core samples were stored in sealed plastic tubes and placed in a refrigerator until processing in the laboratory (Hietz et al., 2013).

\section{WD measurements}

After removing the pith and/or bark, when present, cores were divided into $1-\mathrm{cm}$ segments. For each of these segments, radial position with respect to the inner part of the core, fresh volume, and dry mass were measured. Fresh volume was calculated by the water displacement method and dry mass was obtained after drying the wood segments at $103^{\circ} \mathrm{C}$ for 24-72 h until constant weight. Wood density per segment was defined as dry mass over fresh volume (Williamson \& Wiemann, 2012a). Three different values of WD for each tree were calculated. First, weighted $\mathrm{WD}\left(\mathrm{WD}_{\mathrm{W}}\right)$, which corresponded to the average of all WD values of the $1-\mathrm{cm}$ segments per core, weighted by the stem cross-sectional area that each $1-\mathrm{cm}$ segment represents, and assuming a cylindrical stem (Muller-Landau, 2004). Second, mean WD $\left(W_{M}\right)$, which is the average of all radial WD values per core. Finally, outer $\mathrm{WD}\left(\mathrm{WD}_{\mathrm{O}}\right)$, that is the mean of WD values from the outer $3 \mathrm{~cm}$ of each core. Here, $W_{W}$ represents the most accurate estimation of tree $\mathrm{WD}$, for a given stem diameter, than $\mathrm{WD}_{\mathrm{O}}$ or $\mathrm{WD}_{\mathrm{M}}$, because it takes into account that outer wood segments contribute more to the whole WD of each tree.

Averaged $\mathrm{WD}_{\mathrm{w}}, \mathrm{WD}_{\mathrm{M}}$, and $\mathrm{WD}_{\mathrm{O}}$ values were calculated for each species.

\section{Biomass estimations}

Above-ground biomass (AGB) was calculated for each tree and species using a general allometric model for tropical humid forests (Chave et al., 2014) as: $\mathrm{AGB}=\exp (-1.803-0.9769 \times \mathrm{E}+0.9769 \times$ $\log (\mathrm{WD})+2.6739 \times \log (\mathrm{DBH})-0.0299 \times \log$ $(\mathrm{DBH})^{2}$, where $\mathrm{DBH}$ is given in $\mathrm{cm}$ and $\mathrm{E}$ is a parameter depending on climate. For each tree, three values of $A G B$ were calculated: mean $A G B\left(A_{G B}\right)$, outer AGB $\left(\mathrm{AGB}_{\mathrm{O}}\right)$, and weighted AGB $\left(\mathrm{AGB}_{\mathrm{w}}\right)$; using $\mathrm{WD}_{\mathrm{M}}, \mathrm{WD}_{\mathrm{O}}$ and $\mathrm{WD}_{\mathrm{W}}$ values, respectively (Table 2 ). Then, averaged species values of $A_{G B}, A_{w}$ and $\mathrm{AGB}_{\mathrm{O}}$ were calculated. Finally, percentage errors in AGB estimations per species were calculated by comparing $\mathrm{AGB}_{\mathrm{O}}$ and $\mathrm{AGB}_{\mathrm{M}}$ with $\mathrm{AGB}_{\mathrm{w}}$, as follows:

$$
\begin{gathered}
\% \text { error } \mathrm{AGB}=\left(\left(\mathrm{AGB}-\mathrm{AGB}_{\mathrm{w}}\right) \times 100\right) / \mathrm{AGB}_{\mathrm{w}} \\
(\text { Eq. } 1)
\end{gathered}
$$

where $A G B$ is $A_{G B}$ or $A_{G B}$. 


\section{Statistical analyses}

Radial trends in WD were examined using linear and generalized models predicting WD based on radial distance. As non-homogeneous gradients in WD have been reported for tropical trees (e.g., Williamson and Wiemann, 2010a; Osazuwa-Peters et al., 2014), I fitted linear and non-linear models (i.e., quadratic and cubic) for each species, and compared these models based on Akaike's Information Criterion corrected for small sample sizes ( $\mathrm{AIC}_{\mathrm{C}}$ ). Lower $\mathrm{AIC}_{\mathrm{C}}$ scores indicated a better fit to the data (Burnham \& Anderson, 2002). Then, I examined residual plots to confirm linear or non-linear trends. The possible differences between $\mathrm{WD}_{\mathrm{M}}, \mathrm{WD}_{\mathrm{O}}$ and $\mathrm{WD}_{\mathrm{w}}$, as well as between $\mathrm{AGB}_{\mathrm{w}}, \mathrm{AGB}_{\mathrm{M}}$ and $\mathrm{AGB}_{\mathrm{O}}$, were evaluated using paired Student's t-tests. All statistical analyses were conducted in the software R 3.2.2 (R Development Core Team, 2016).

\section{Results}

\section{Radial variation in WD}

Eight out of eighteen species had significant radial trends in WD (44.4\%; Table 2, Fig. 1). Among these species, radial changes in WD were best fitted by linear models in three species (16.6\%, Table 2$)$. Two of these species (i.e., Ocotea sericea and Podocarpus oleifolius) are shade-tolerants and had negative gradients in WD (e.g., WD decreased towards the bark), while one species (i.e., Axinea macrophylla) is light-demanding and had a positive gradient in WD (i.e., WD increased from pith to bark). Non-linear models (i.e., quadratic or cubic equations) best explained radial gradients in WD in five species $(27.7 \%$, Table 2 ), which correspond to long-lived, light-demanding species (Table 1). In these five species, WD tends to follow a U-shaped pattern where WD is higher close to the pith and bark, but relatively low at intermediate stem diameters.

Weighted WD $\left(\mathrm{WD}_{\mathrm{w}}\right)$ differed significantly from mean WD $\left(\mathrm{WD}_{\mathrm{M}}\right.$; t: 18.86, $\left.\mathrm{p}<0.001\right)$ and outer WD $\left(\mathrm{WD}_{\mathrm{O}}\right.$; t: 4.67, $\left.\mathrm{p}<0.001\right)$, whereas $\mathrm{WD}_{\mathrm{M}}$ and $\mathrm{WD}_{\mathrm{O}}$ did not differ significantly (t: $0.17, p>0.05)$. The use of $\mathrm{WD}_{\mathrm{M}}$, instead of $\mathrm{WD}_{\mathrm{W}}$, led to under-estimations of AGB (e.g., $A_{G B}$ ) in most of the species (Table 2, Fig. $2)$. The percentage error in $A_{G B}$ estimations averaged $-7.66 \%$, ranging from $2.35 \%$ in Ocotea calophylla to -11.70 in Myrsine coriacea (Table 2). Similarly, the use of $\mathrm{WD}_{\mathrm{O}}$ caused under-estimations in AGB for all species, excepting Hedyosmum parvifolium (Table 2, Fig. 2). The percentage error in $\mathrm{AGB}_{\mathrm{O}}$ estimations varied from 2.25 in Ocotea calophylla, to $-22.0 \%$ in Ocotea sericea (Table 2), averaging $-5.56 \%$. The percentage errors in $\mathrm{AGB}_{\mathrm{M}}$ and $\mathrm{AGB}_{\mathrm{O}}$ did not differ significantly from one another (t:0.79, $\mathrm{p}>0.44) . \mathrm{AGB}_{\mathrm{w}}$ differed significantly from $\mathrm{AGB}_{\mathrm{M}}(\mathrm{t}: 3.98, \mathrm{p}<0.001)$ and $\mathrm{AGB}_{\mathrm{O}}(\mathrm{t}: 4.23, \mathrm{p}<0.001)$, while $\mathrm{AGB}_{\mathrm{M}}$ and $\mathrm{AGB}_{\mathrm{O}}$ were not significantly different ( $t: 1.99, \mathrm{p}>0.05)$.

\section{Discusion}

\section{Radial trends in WD}

Negative radial shifts in WD (i.e., decreases of WD towards the bark) were found in two shade-tolerant species, namely O. sericea and P. oleifolius (Fig. 1,

Table 1. Study species, family, number of trees sampled (n), mean diameter at breast height (DBH), mean height (H) and ecological guild, based on Mahecha et al. (2012), of 18 tree species from a high-Andean forest

\begin{tabular}{|c|c|c|c|c|c|c|}
\hline Species & Code & Family & $\mathrm{n}$ & DBH $(\mathrm{cm})$ & $\mathrm{H}(\mathrm{m})$ & Ecological guild \\
\hline Axinea macrophylla & Axi_mac & Melastomataceae & 5 & 29.2 & 18 & Light-demanding \\
\hline Brunellia acutangula & Bru_acu & Brunelliaceae & 5 & 24.2 & 13 & Light-demanding, long-lived \\
\hline Clethra repanda & Cle_rep & Clethraceae & 3 & 26.2 & 16 & Light-demanding, long-lived \\
\hline Clusia multiflora & Clu_mul & Clusiaceae & 4 & 26.4 & 13 & Shade-tolerant \\
\hline Clusia sp. & Clu_sp & Clusiaceae & 3 & 28.6 & 15 & Shade-tolerant \\
\hline Drymis granadensis & Dry_gra & Winteraceae & 5 & 30.2 & 13 & Light-demanding, long-lived \\
\hline Hedyosmum crenatum & Hed_cre & Chloranthaceae & 4 & 26.2 & 10 & Light-demanding, long-lived \\
\hline Hedyosmum parvifolium & Hed_par & Chloranthaceae & 3 & 25.8 & 9 & Light-demanding, long-lived \\
\hline Myrsine coriacea & Myr_cor & Primulaceae & 3 & 25.9 & 11 & Shade-tolerant \\
\hline Ocotea calophylla & Oco_cal & Lauraceae & 3 & 31.0 & 13 & Shade-tolerant \\
\hline Ocotea sericea & Oco_ser & Lauraceae & 3 & 29.1 & 12 & Shade-tolerant \\
\hline Podocarpus oleifolius & Pod_ole & Podocarpaceae & 5 & 30.6 & 13 & Shade-tolerant \\
\hline Prunus buxifolia & Pru_bux & Rosaceae & 4 & 31.1 & 14 & Shade-tolerant \\
\hline Symplocos mucronata & Sym_muc & Symplocaceae & 3 & 27.2 & 11 & Shade-tolerant \\
\hline Tibouchina lepidota & Tib_lep & Melastomataceae & 4 & 29.3 & 9 & Light-demanding \\
\hline Weinmannia auriculata & Wei_aur & Cunoniaceae & 6 & 30.2 & 15 & Light-demanding, long-lived \\
\hline Weinmannia pinnata & Wei_pin & Cuniniaceae & 3 & 25.1 & 13 & Light-demanding, long-lived \\
\hline Weinmannia tomentosa & Wei_tom & Cuniniaceae & 3 & 25.3 & 11 & Light-demanding, long lived \\
\hline
\end{tabular}



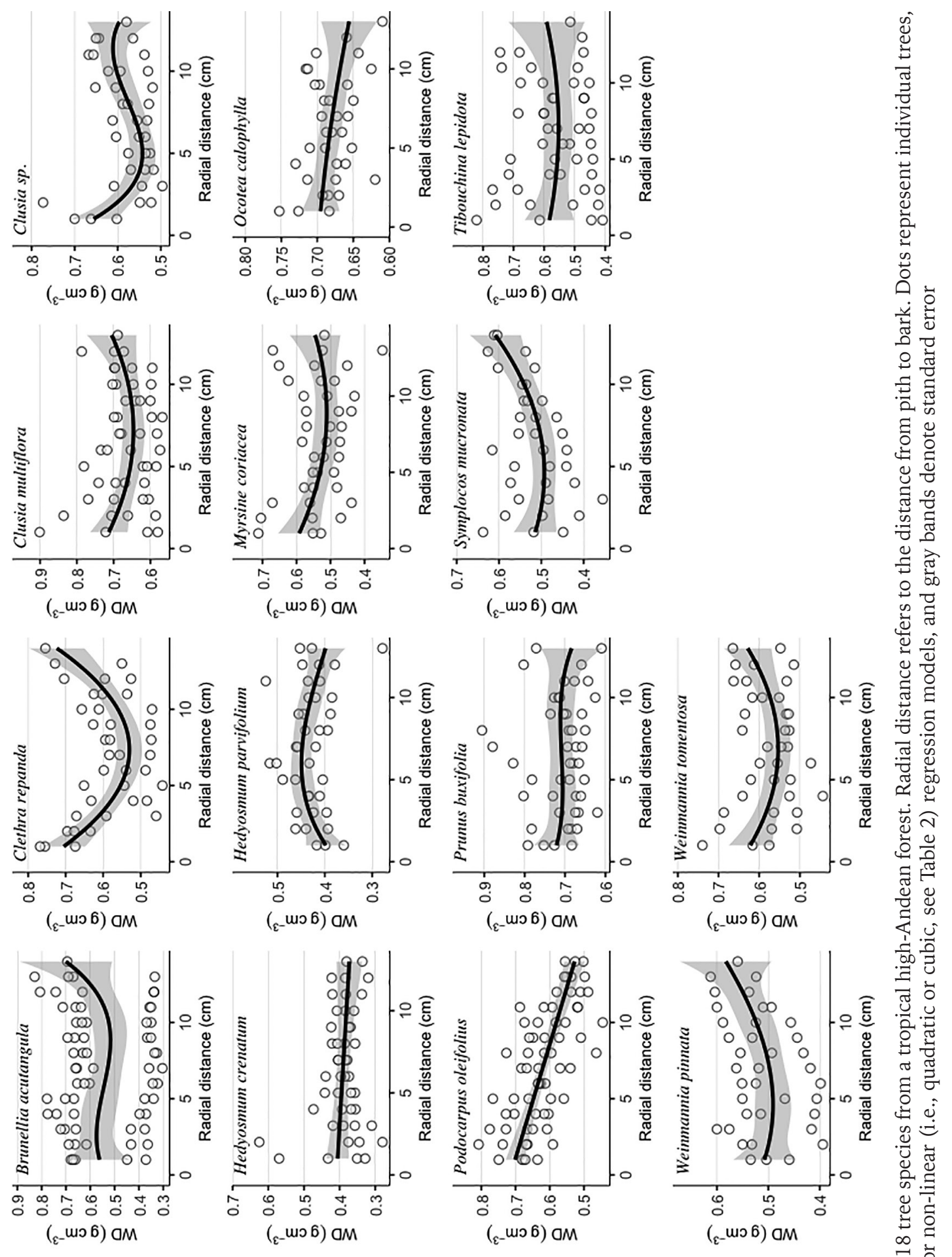

.
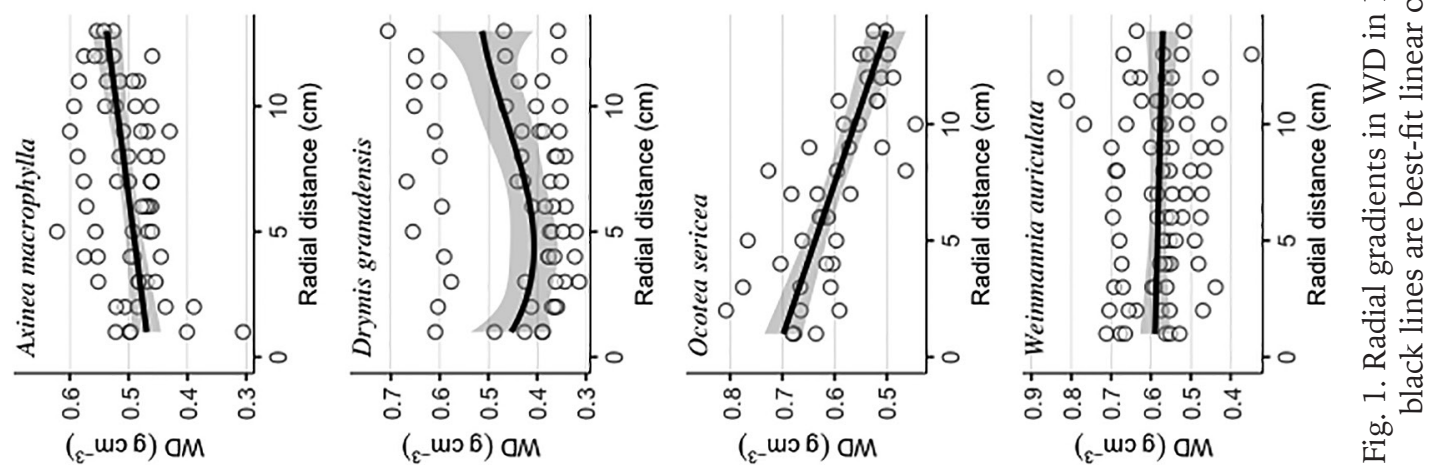
Table 2). There are two possible explanations to the occurrence of negative radial trends in WD in these species. First, these gradients may be the product of the deposition of wood extractives in the inner wood during heartwood formation (Lehnbach et al., 2019), because extractives can increase density via increments in wood mass. This would be the case of $O$. sericea, as heartwood was present in all cores of this species. Since wood extractives are involved in plant defense (e.g., Hillis, 1987), the negative gradient of WD in O. sericea may be related to defensive needs. An alternative explanation is that negative gradients in WD reflect the wood allocation strategy of shade-tolerants during ontogeny (e.g., Woodcock \& Shier, 2002). For instance, juveniles of shade-tolerant species typically produce dense wood (e.g., Hietz et al., 2013; Plourde et al., 2015), which can limit growth, but may be advantageous to survive in the forest understory because it reduces the risks of pathogen attacks or mechanical damage due to falling branches (e.g., Alvarez-Claire \& Kitajima, 2007). Later, when adults have reached more favorable canopy layers, they tend to produce lighter wood probably to favor tree growth (e.g., Woodcock \& Shier, 2002). This ontogenetic pattern of WD variation may hold true for P. oleifolius, which is a shade-tolerant species representative of old-growth, tropical high-Andean forests.

In contrast, $A$. macrophylla, a light-demanding species, had a positive gradient in WD (i.e., increments from pith to bark; Table 2, Fig. 1). This is in agreement with a number of studies that have reported radial increments of WD in pioneer and light-demanding species (e.g., Woodcock \& Shier, 2002; Nock et al., 2009; Hietz et al., 2013; Plourde et al., 2015). Radial increments of WD are thought to provide benefits in terms of growth and mechanical stability (Woodcock \& Shier, 2002; Hietz et al., 2013; Bossu et al., 2018). At early ontogenetic stages, light-demanding species may benefit from producing low density wood, because these species tend to regenerate in canopy gaps, and light wood may allow faster growth rates in light environments (e.g., Woodcock \& Shier, 2002). Then, as adults, light-demanding species tend to produce dense wood in the outer part of the trunk (Woodcock \& Shier, 2002), which may allow them to achieve needed mechanical strength at a lower construction cost than tree species with denser wood (Hietz et al., 2013; Bossu et al., 2018). These benefits in growth and mechanical stability may be at the cost of survival, particularly in juveniles, since low-WD species have higher risks of mechanical or pathogen damage (e.g., Alvarez-Clare \& Kitajima, 2007), as well as of hydraulic dysfunction (e.g., Santiago et al., 2018). Another possible, and indirect, cost associated to radial increments of WD is higher stem maintenance costs (i.e., stem respiration), since light-demanding species tend to build thicker stems than shade-tolerant species, and maintenance costs are thought to increase with stem surface area (e.g., Larjavaara \& Muller-Landau, 2010).

Non-linear, U-shaped, radial trends were found in five species, all of them corresponding to longlived, light-demanding species (Table 1, 2; Fig. 1). While U-shaped trends in WD have been reported previously for tropical trees in lowland humid forests

Table 2. Best-fitting models, model parameters, WD values, AGB values, and percentage errors in AGB (mean: \% AGBM, outer: \% AGBO) for 18 tree species from a tropical high-Andean forest. Significant P-values $(<0.05)$ are shown in bold. See Methods for trait abbreviations

\begin{tabular}{|c|c|c|c|c|c|c|c|c|c|c|c|}
\hline \multirow{2}{*}{ Species } & \multicolumn{3}{|c|}{ Models } & \multicolumn{3}{|c|}{ WD } & \multicolumn{5}{|c|}{ AGB } \\
\hline & Model & $\mathrm{R}^{2}$ & $\mathrm{P}$ & $\mathrm{WD}_{\mathrm{M}}$ & $\mathrm{WD}_{\mathrm{O}}$ & $\mathrm{WD}_{\mathrm{w}}$ & $\mathrm{AGB}_{\mathrm{O}}$ & $\mathrm{AGB}_{\mathrm{M}}$ & $\mathrm{AGB}_{\mathrm{W}}$ & $\% \mathrm{AGB}_{\mathrm{M}}$ & $\% \mathrm{AGB}_{\mathrm{O}}$ \\
\hline Axinea macrophylla & Linear & 0.12 & $<0.01$ & 0.50 & 0.53 & 0.53 & 412.3 & 435.3 & 431.1 & -4.16 & 1.25 \\
\hline Brunellia acutangula & Cubic & -0.04 & $>0.05$ & 0.55 & 0.56 & 0.60 & 502.3 & 519.4 & 548.1 & -9.15 & -7.31 \\
\hline Clethra repanda & Quadratic & 0.14 & $<0.05$ & 0.59 & 0.62 & 0.64 & 534.2 & 563.6 & 580.7 & -8.19 & -3.19 \\
\hline Clusia multiflora & Quadratic & 0.03 & $>0.05$ & 0.66 & 0.67 & 0.72 & 484.9 & 491.8 & 524.1 & -7.51 & -6.39 \\
\hline Clusia sp. & Cubic & 0.03 & $>0.05$ & 0.58 & 0.59 & 0.63 & 452.5 & 463.6 & 490.8 & -7.78 & -5.61 \\
\hline Drymis granadensis & Cubic & 0.08 & $<0.05$ & 0.43 & 0.47 & 0.48 & 323.4 & 342.9 & 350.8 & -9.22 & -5.97 \\
\hline Hedyosmum crenatum & Linear & 0.01 & $>0.05$ & 0.39 & 0.38 & 0.45 & 264.6 & 263.2 & 299.4 & -11.51 & -13.31 \\
\hline Hedyosmum parvifolium & Cubic & 0.04 & $>0.05$ & 0.42 & 0.43 & 0.42 & 383.0 & 388.9 & 383.0 & 0.00 & 1.5 \\
\hline Myrsine coriacea & Quadratic & 0.14 & $>0.05$ & 0.53 & 0.52 & 0.60 & 646.0 & 661.2 & 753.7 & -11.7 & -13.5 \\
\hline Ocotea calophylla & Quadratic & 0.10 & $>0.05$ & 0.68 & 0.58 & 0.72 & 833.8 & 0.348 & 812.0 & 2.35 & 2.25 \\
\hline Ocotea sericea & Linear & 0.18 & $<0.01$ & 0.60 & 0.51 & 0.66 & 695.9 & 809.7 & 896.6 & -9.88 & -22.0 \\
\hline Podocarpus oleifolius & Linear & 0.43 & $<0.001$ & 0.61 & 0.55 & 0.67 & 580.2 & 513.6 & 629.4 & -7.90 & -17.19 \\
\hline Prunus buxifolia & Cubic & 0.61 & $>0.05$ & 0.70 & 0.69 & 0.76 & 496.0 & 490.6 & 535.0 & -7.47 & -7.69 \\
\hline Symplocos mucronata & Quadratic & 0.21 & $<0.01$ & 0.51 & 0.54 & 0.56 & 374.5 & 402.4 & 410.0 & -8.13 & -0.97 \\
\hline Tibouchina lepidota & Quadratic & -0.03 & $>0.05$ & 0.56 & 0.57 & 0.61 & 415.1 & 426.4 & 452.8 & -8.66 & -7.51 \\
\hline Weinmannia auriculata & Linear & -0.01 & $>0.05$ & 0.58 & 0.60 & 0.63 & 515.2 & 532.3 & 561.1 & -8.17 & -5.24 \\
\hline Weinmannia pinnata & Cubic & 0.15 & $<0.05$ & 0.51 & 0.55 & 0.56 & 433.1 & 476.8 & 474.9 & -8.78 & -0.79 \\
\hline Weinmannia tomentosa & Quadratic & 0.16 & $<0.01$ & 0.58 & 0.59 & 0.63 & 485.6 & 497.5 & 526.6 & -7.84 & -5.11 \\
\hline
\end{tabular}


(Wiliamson et al., 2012; Osazuwa-Peters et al., 2014), the results of this study suggest that they are also common in tropical high-Andean forests. Yet, a clear understanding of the factors driving these radial trends in WD is still lacking (e.g., Osazuwa-Peters et al., 2014). In comparison to lowland humid forests, tropical high-Andean forests tend to have lower stature, as well as a more open and less stratified canopy (e.g., Asner et al., 2014). As a consequence, I speculate that a large fraction of high-Andean tree species likely regenerates in relatively well-lit environments. In this context, although the species that showed U-shape radial trends in WD start producing wood of intermediate (c. 0.50-0.70) density, they might benefit from the prevailing gap openings by investing in lighter wood at small and intermediate stem diameters. Later, at larger diameters, these species may produce denser wood, either because canopy gaps are closed and light availability is limited, or because they have reached the canopy and need to favor crown expansion and/or increase mechanical stability. Further studies on ontogenetic shifts in light availability and species demographic rates are needed to explain the occurrence of U-shaped radial trends in WD that seem to be common among tropical high-Andean trees.

Density is an integrative property of wood that is influenced, in angiosperms, by the relative abundance and morphology of three cell types: vessels, fibers and parenchyma cells (e.g., Carlquist, 2001). In particular, fibers are thought to be the main drivers of WD variations (e.g., Mártinez-Cabrera et a., 2009; Zieminska et al., 2015), as they are the most abundant cell type and tend to have thicker walls than vessels or parenchyma cells (Zieminska et al., 2013). Therefore, radial variations in WD likely reflect radial shifts in wood anatomy, particularly in fiber fractions and wall thickness (Mc Donald et al., 1995). Yet, a recent study found that the anatomical drivers of radial variations in WD can vary substantially among species (Rungwattana \& Hietz, 2017). The extent to which wood anatomical traits explain radial shifts in WD is a subject that merits further study. In addition, it is important to note that in some species, particularly in those without significant radial shifts in WD, conspecific individuals can show divergent ontogenetic trends in WD (Fig. 1). Possibly, differences in growing conditions (i.e., light availability and edaphic factors) among individuals may drive these divergent trends. Future research should consider larger sample sizes, and take into account individual growing conditions, to better understand intraspecific variation in ontogenetic trends in WD.

\section{Radial trends in WD and above-ground biomass estimations}

Wood density is, after stem size, the most important predictor of above-ground biomass (AGB; Chave et al., 2014). Then, not taking into account radial trends in WD may led errors in ABG estimations

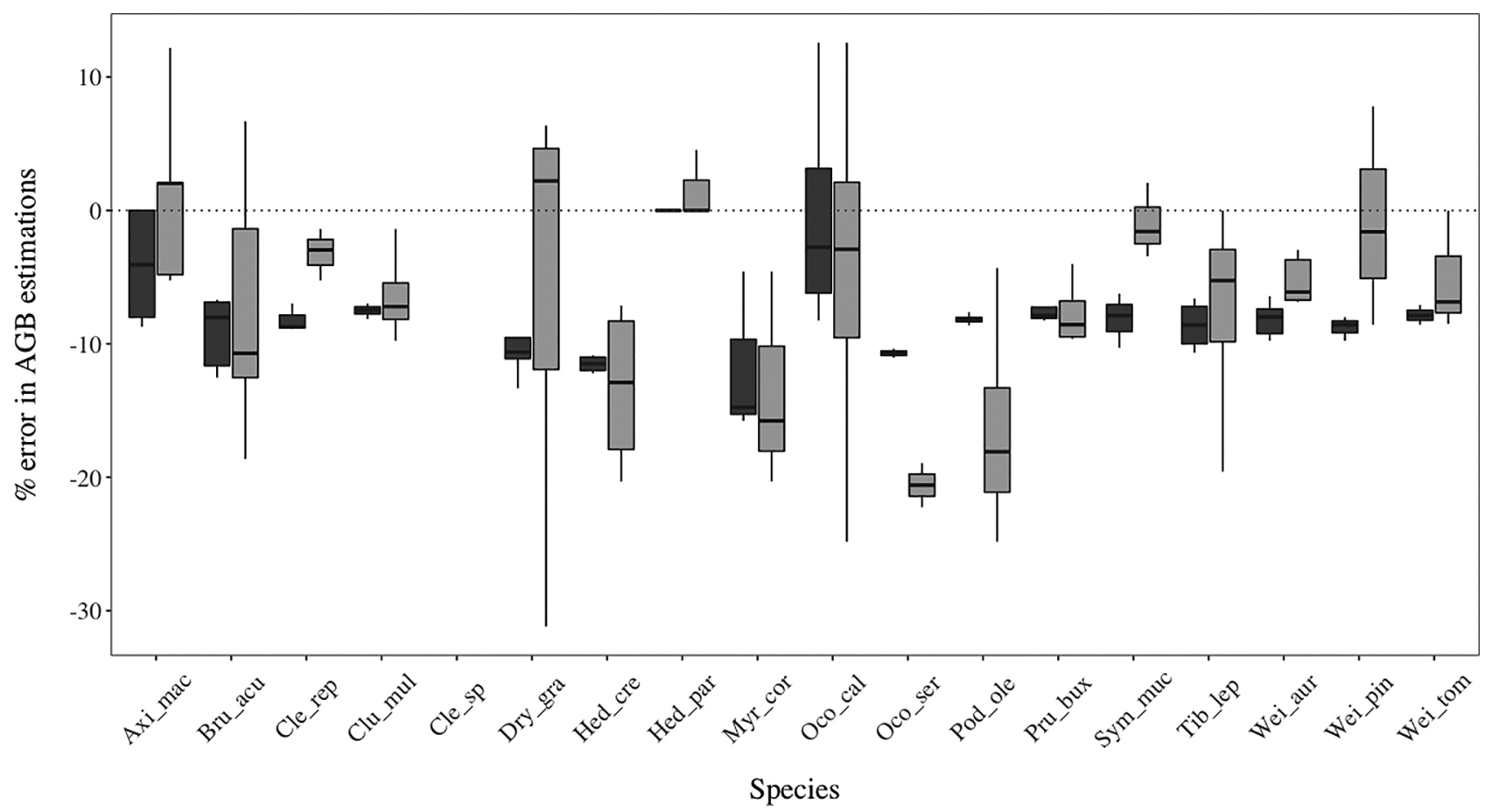

Fig. 2. Percentage errors in AGB estimations for 18 tree species from a tropical high-Andean forest. Black and gray bars represent mean $\mathrm{AGB}\left(\mathrm{AGB}_{\mathrm{M}}\right)$ and outer $\mathrm{AGB}\left(\mathrm{AGB}_{\mathrm{O}}\right)$, respectively. Error bars denote standard deviation. See Table 1 for species codes 
(e.g., Schüller et al., 2013; Osazuwa-Peters et al., 2014). The results of this study indicate that not considering radial trends in WD led, in general, to under-estimations of AGB in most of the study species (Fig. 2, Table 2). This indicates that some tropical high-Andean forests may probably have higher AGB (e.g., Álvarez-Davila et al., 2017; Rodríguez-Alarcon et al., 2018; Calbi et al., 2021), and store more biomass carbon, than have been previously estimated. Although forest biomass estimation is increasingly based on remote sensing techniques such as hyperspectral optical imaging and LIDAR (e.g., Réjou-Mechain et al., 2017), it still depends to some degree on field data at the species and stand level (Chave et al., 2014). This suggests that although the averaged percentage errors in AGB estimation found in this study are relatively small $(-7,66 \%$ using $\mathrm{WD}_{\mathrm{M}}$, and $-5.66 \%$ using $\mathrm{WD}_{\mathrm{O}}$ ), they may lead to misleading interpretations of forest carbon dynamics, if they are uncritically propagated to the stand or regional level.

Furthermore, for most of the studied species, the percentage errors in AGB estimations resulting from using $W_{\mathrm{M}}$ did not differ considerably from those obtained from using $\mathrm{WD}_{\mathrm{O}}$ (Fig. 2). Therefore, instead of using $\mathrm{WD}_{\mathrm{M}}, \mathrm{WD}_{\mathrm{O}}$, or averaged $\mathrm{WD}$ values from global repositories, a better practice to reduce biases in AGB estimations in these high-Andean forests would be to take wood cores to the center of the stem, and calculate WD for different segments of each core, weighting them by the stem cross sectional area they represent. Yet, this practice may not be feasible for studies that consider a large number of species or individuals. Finally, WD can vary not only radially, but also axially from the base of the stem toward tree top (e.g., Lachenbruch et al., 2011). Then, I suggest that future studies should consider the effects of axial variations in WD on AGB estimations.

\section{Conclusions}

This study examined radial variations of WD, and their implications for above-ground biomass (AGB) estimations, in 18 tree species with contrasting shade-tolerance in a tropical high-Andean forest. Significant radial variations in WD were found in eight species. Among these species, one had a positive and linear trend, two showed negative and linear patterns, and five species had U-shaped radial trends. The prevalence of U-shaped radial trends in WD may be related to the relatively open and less stratified canopy of the study forest. Not taking into account radial trends in WD led in general to under-estimations of AGB in most of the study species, suggesting that tropical high-Andean forests may possibly store more biomass carbon than previously assumed.
These insights are important to increase our knowledge on ontogenetic shifts in WD, and then to redefine the functional value of WD among tropical high-Andean tree species. Moreover, the fact that radial trends in WD are common among the study species suggests that interspecific comparisons of WD in high-Andean forests should consider the effect of stem size. The results of this study may also help to reduce uncertainties associated to AGB estimations in high-Andean forests which, in turn, is important to have a better understanding of the role that these forests play on the global carbon cycle and the provision of ecosystem services.

\section{Acknowledgements}

The author is very grateful to Gustavo Loboguerrero, who is the owner of the forest where the wood sampling took place. The author also thanks Favio Avila and Silvana Combita for their help in botanical identification; Adriana Molina, Nataly Garcia, and Luz Helena Di Giorgi for their assistance in sampling the wood cores; Carolina Sarmiento for her assistance with data visualization, as well as Camille Ziegler for insightful comments on a previous version of the manuscript. Finally, the author acknowledges financial support from Colciencias (Colombian Agency for Science and Technology).

\section{References}

Alvarez-Clare S \& Kitajima K (2007) Physical defense traits enhance seedling survival of neotropical tree species. Functional Ecology 21: 1044-1054. doi:10.1111/j.1365-2435.2007.01320.x.

Álvarez-Dávila E, Cayeula L, González-Caro S, Aldana AM, Stevenson PR, Phillips O, Cogollo A, Peñuela MC, von Hildebrand P, Jiménez E, Melo O, Londoño-Vega AC, Mendoza I, Velásquez O, Fernández F, Serna M, Velásquez-Rua C, Benítez D \& Rey-Benayas JM (2017) Forest biomass density across large climate gradients in northern South America is related to water availability but not with temperature. PLoS One: e0171072. doi:10.1371/journal.pone.0171072.

Anten NPR \& Schieving F (2010) The role of wood mass density and mechanical constraints in the economy of tree architecture. The American Naturalist 175: 250-260. doi:10.1086/649581.

Armenteras D, Gast F \& Villareal H (2003) Andean forest fragmentation and the representativeness of protected natural areas in the Eastern Andes, Colombia. Biological Conservation 113: 245-256. Asner GP, Anderson CB, Martin RE, Knapp DE, Tupayachi R, Sinca F \& Malhi Y (2014) Landscape-scale changes in forest structure and functional traits 
along an Andes-to-Amazon elevation gradientBiogeosciences 11: 843-856. doi:10.5194/bg-11843-2014.

Avella A, Torres S, Gomez W \& Pardo M (2014) Los páramos y bosques alto-andinos del páramo de Montequiva o paramo de Marlos (Guatavita, Cundinamarca, Colombia): caracterización ecológica y estado de conservación. Biota Colombiana 15: 3-39.

Baraloto C, Quentin M, Suzanne R, Hérault B, Valencia R, Blanc L, Fine PV \& Thompson J (2012) Rapid simultaneous estimation of aboveground biomass and tree species diversity across Neotrpical forets: A comparison of field inventory methods. Biotropica 45: 1-11. doi:10.1111/btp.12006.

Bossu J, Lehnebach R, Corn S, Regazzi A, Beauchêne J \& Clair B (2018) Interlocked grain and density patterns in Bagassa guianensis: changes with ontogeny and mechanical consequences for trees. Trees 32: 1643-1655. doi:10.1007/s00468-0181740-x.

Burnham KP \& Anderson DR (2002) Model selection and multimodel inference: A practical information-theoretic approach. Springer, New York, USA.

Chave J, Coomes D, Jansen S, Lewis SL, Swenson NG \& Zanne AE (2009) Towards a worldwide wood economics spectrum. Ecology Letters 12: 351366. doi:10.1111/j.1461-0248.2009.01285.x.

Chave J, Réjou-Méchain M, Búrquez A, Chidumayo E, Colgan MS, Delitti WBC, Duque A, Eid T, Fearnside PM, Goodman RC, Henry M, Martínez-Yrízar A, Mugasha WA, Muller-Landau HC, Mencuccini M, Nelson BW, Ngomanda A, Nogueira EM, Ortiz-Malavassi E, Pélissier R, Ploton P, Ryan CM, Saldarriaga JG \& Vieilledent G (2014) Improved allometric models to estimate the aboveground biomass of tropical trees. Global Change Biology 20: 3177-3190. doi.org/10.1111/gcb.12629.

Calbi M, Fajardo-Gutierrez F, Posada JM, Lücking R, Brokamp G \& Borsch T (2021) Seeing the wood despite the trees: Exploring human disturbance impact on plant diversity, community structure, and stand biomass in fragmented high Andean forests. Ecology and Evolution 11: 2110-2172. doi:10.1002/ece3.7182.

Cantillo EE, Rodríguez KJ \& Avella EA (2004) Diversidad y caracterización florística estructural de la vegetación arbórea en la Reserva Forestal Carpatos (Guasca-Cundinamarca). Revista Colombia Forestal 8: 4-21. doi:10.14483/udistrital.jour.colomb.for.2004.1.a01.

Fortunel C, Ruelle J, Beauchene J, Fine PVA \& Baraloto C (2013) Wood specific gravity and anatomy of branches and roots in 113 Amazonian rainforest tree species across environmental gradients. New Phytologist 202: 79-94. doi:10.1111/nph.12632.
Hietz P, Valencia R \& Wright SJ (2013) Strong radial variation in Wood density follows a uniform pattern in two neotropical rain forests. Functional Ecology 27: 684-692. doi:10.1111/13652435.12085.

Hillis WE (1987) Heartwood and tree exudates. Springer, Berlin.

King DA, Davies SJ, Tan S \& Noor NS (2006) The role of wood density and stem support costs in the growth and mortality of tropical trees. Journal of Ecology 94: 670-680. doi:10.1111/j.13652745.2006.01112.x.

Lachenbruch B, Moore JR \& Evans R (2011) Radial variation in wood structure and function in woody plants, and hypotheses for its occurrence: Size- and age-related changes in tree structure and function (ed. by FC Meinzer, B Lachenbruch \& Dawson TE) Springer, New York, NY, USA, pp. 121-164. doi:10.1007/978-94-007-1242-3_5.

Larjavaara M \& Muller-Landau H (2010) Rethinking the value of high wood density. Functional Ecology 24: 701-705. doi:10.1111/j.13652435.2010.01698.x.

Lehnbach R, Bossu J, Va S, Morel H, Amusant N, Nicolini E \& Beauchêne J (2019) Wood density variations of legume trees in French Guiana along the shade tolerance continuum: heartwood effects on radial patterns and gradients. Forests 10: 1-22. doi:10.3390/f10020080.

Mahecha G, Escobar A, Camelo D, Rozo A \& Barreto D (2004) Vegetación del territorio CAR: 450 especies de sus llanuras y montañas. Corporación Autónoma Regional de Cundinamarca.

Martínez-Cabrera H, Jones CA, Espino S \& Schenk HJ (2009) Wood anatomy and density in shrubs: Responses to varying aridity along transcontinental transects. American Journal of Botany 96: 1388-1398.

Mittermeier RA, Robles PG, Hoffman M, Pilgrim J, Brooks TM, Mittermeier CG, Lamoreux J \& Da Fonseca GAB (2003) Hotspots revisited. Earth's biologically richest and most endangered terrestrial ecoregions. CEMEX, Mexico City.

Muller-Landau H (2004) Interspecific and Inter-site variation in Wood specific gravity of tropical trees. Biotropica 36: 20-32.

Myers N, Mittermeier R, Mittermeier C, DaFonesca G \& Kent J (2000) Biodiversity hotspots for conservation priorities. Conservation Biology 403: 853.

Nock C, Geihofer D, Grabner M, Baker PJ, Bunyavejchewin S \& Hietz P (2009) Wood density and its radial variation in six canopy tree species differing in shade-tolerance in western Tailand. Annals of Botany 104: 297-306.

Osazuwa-Peters O, Wright JS \& Zanne AE (2014) Radial variation in wood specific gravity of tropical 
tree species differing in growth-mortality strategies. American Journal of Botany 101: 803-811.

Plourde BT, Boukill VK \& Chazon RL (2015) Radial changes in wood specific gravity of tropical trees: inter-and intraspecific variation during secondary succession. Functional Ecology 29: 111-120.

Réjou-Méchain $M$, Tanguy A, Piponiot $C$, Chave J \& Hérault B (2017) BIOMASS: An R package for estimating above-ground biomass and its uncertainty in tropical forests. Methods in Ecology and Evolution 8: 1163-1167.

Rodríguez-Alarcón S, Rodríguez-Eraso N, Pineda-Rincón I \& López-Camacho R (2018) Effects of fragmentation on functional diversity associated with aboveground biomass in a high Andean forest in Colombia. Landscape Ecology 33: 18511864.

Rungwattana K \& Hietz P (2017) Radial variation of wood functional traits reflects size- related adaptations of tree mechanics and hydraulics. Functional Ecology 32: 260-272.

Schüller E, Martínez-Ramos M \& Hietz P (2013) Radial gradients in wood specific gravity, water gas content in trees of a Mexican tropical rain forest. Biotropica 45: 280-287.

Ter Steege H, Pitman NCA, Phillips OL, Chave J, Sabatier D, Duque A, Molino JF, Prévost MF, Spichiger R, Castellanos H, von Hildebrand P \& Vásquez R (2006) Continental-scale patterns of canopy tree composition and function across Amazonia. Nature 443: 444-447.

Visser MD, Bruijning M, Wright SJ, Muller-Landau HC, Jongejans E, Comita L \& Kroon H (2016) Functional traits as predictor of vital rates across the life cycle of tropical trees. Functional Ecology 30: 168-180.
Wiemann MC \& Williamson GB (1989) Wood specific gravity gradients in tropical dry and montane rain forest trees. American Journal of Botany 76: 924-928.

Wiemann MC \& Williamson GB (2002) Geographic variation in wood specific gravity: effects of latitude, temperature, and precipitation. Wood Fiber 34: 96-107.

Williamson GB \& Wiemann MC (2010a) Age-dependent radial increases in wood specific gravity of tropical pioneers in Costa Rica. Biotropica 42: 590-597.

Williamson GB \& MC Wiemann (2010b) Measuring Wood specific gravity... correctly. American Journal of Botany 97: 519-524.

Williamson GB, Wiemann MC \& Geaghan JP (2012) Radial wood allocation in Schizolobium parhyba. Journal of Botany 99: 1010-1019. doi: 10.3732/ ajb.1100516.

Woodcock DW \& Shier AD (2002) Wood specific gravity and its radial variations: the many ways to make a tree. Trees 16: 437-443.

Zanne AE, Lopez-Gonzalez G, Coomes DA, Ilic J, Jansen S, Lewis SL, Miller RB, Swenson NG, Wiemann MC \& Chave J (2009) Global wood density database. doi:10.5061/dryad.234.

Zieminska K, Butler DW, Gleason SM, Wright IJ \& Westoby M (2013) Fibre wall and lumen fractions drive Wood density variation across 24 Australian angiosperms. AoB PLANTS 5: 1-13.

Zieminska K, Westoby M \& Wright IJ (2015) Broad anatomical variation within a narrow wood density range: A study of twig Wood across 69 Australian Angiosperms. PLOS One 10: 1-25. 